\title{
The effect of individual characteristics on organizational citizenship behavior (OCB) with intrinsic motivation as an intervening variable in BUMDES
}

\author{
Epsilandri Septyarini ${ }^{1)}$, Muhammad Hengki Setiawan ${ }^{2)}$ \\ ${ }^{1)}$ Sarjanawiyata Tamansiswa University of Yogyakarta \\ ${ }^{2)}$ Alumnus of Sarjanawiyata Tamansiswa University of Yogyakarta \\ Corresponding author: epsilandriseptyarini@ustjogja.ac.id
}

\begin{abstract}
BUMDes Panggung Lestari in Sewon, Bantul currently still lacks in development. Even if BUMDes Panggung Lestari has a fairly large tracts of land, it cannot be utilized optimally due to inadequate human resources and lack of vision and missions of the organization to develop the economy of the community members of Panggungharjo Village, creating uneven economic development. This study aims at determining the factors affecting OCB in BUMDes Panggung Lestari in Panggungharjo Village, Sewon District, Bantul Regency. On the other hand, this study also aims at enabling BUMDes Panggung Lestari to improve the quality of its human resources to become a pioneer for other BUMDes. The sampling method used in this study was accidental sampling with 82 respondents. The analytical methods used in this study were T-test and Sobel test. The results of the study showed that individual characteristics have a significant, positive effect on OCB with a significance value of 0.000 , individual characteristic has a significant effect on intrinsic motivation with a significance value of 0.005 , and intrinsic motivation has a positive effect on OCB with a significance value of 0.000 . OCB with intrinsic motivation as an intervening variable has a significance value of 0.013. It is expected that this study can be used to measure individual characteristics and intrinsic motivation for $O C B$.
\end{abstract}

Keywords: Individual Characteristics, Intrinsic Motivation, Organizational Citizenship Behavior

\section{Introduction}

A Village-Owned Enterprise, hereinafter referred to as BUMDes, is a rural economic institution/body which has a legal entity established by the Ministry of Villages to cover underdeveloped regions to make the economy and improvement of the regions to be evenly distributed. BUMDes is managed economically, independently, and professionally with the capital from the Ministry of Villages and village wealth. BUMDes is established with the aims of obtaining profits to strengthen the Village Own-Source Revenue (Pendapatan Asli Desa/PADes), improving the village economy, and improving the welfare of the village community. Based on the description, the researcher was interested to study the Village-Owned Enterprise (BUMDes) Panggung Lestari located in Panggungharjo Village, Sewon, Bantul, Special Region of Yogyakarta. Currently, BUMDes Panggung Lestari is facing a situation of lack of motivation within employees to improve the management in each unit. The researcher was interested more deeply in conducting a study of how to make the employees in BUMDes Panggung Lestari have loyalty to the organization, by considering individual characteristics and motivation within themselves to create good characters and loyalty to the organization.

\section{Literature Review \\ Individual Characteristics}

Caligiuri (2000) expresses that the theory of evolutionary psychology can apply to the success of strangers for two reasons. First, because variations in personality traits enable individuals to successfully fill in different positions. Second, because personality traits (Big Five) are applicable universal, adaptive mechanisms, regardless of individual nationality or culture of the assignment place. Graf (2004) expresses the importance of effective profiles based on skills such as intercultural communication competencies and intercultural sensitivity that are difficult to learn or can be learned in the long run, compared to skills such as language and knowledge about foreign cultures that can be learned in a short period of time.

Abdurahman (2012) expresses that personality is reflected on traits and attitudes of a person which distinguishes one culture from another. Hidayatullah, Noviekayati, \& Saragih (2018) express that a dynamic organization in an individual as a psycho-physical system exists in each individual to determine how to adapt in the work environment. Personality is described as a self-ideal that affects a person's behavior uniquely. Such behavior can change through various stages in a process, including the process of learning, experience, education, etc. This opinion is also supported by the study of Wahyudi (2014) that personality adjusts to environmental conditions. Bhatti, Kaur, \& Battour (2013) argue that the five major of personality traits (extroversion, agreeableness, conscientiousness, neuroticism, and openness) do not have a theoretical perspective but reflect the natural language used by other people.

\section{Intrinsic Motivation}


Baard, Deci, \& Ryan (2004) express that people who become volunteers for good reasons are regulating their behavior through the actions they identify. At the right end of the continuum lies intrinsic motivation, where people engage in an activity because it is fun and interesting. This is the most determined form of motivation and is associated with positive results such as perseverance and quality of performance

Puspitasari (2019) defines intrinsic motivation as one of the stimuli or impulses in an individual to do something in order to achieve a certain or desired goal. Kurniawan \& Hutami (2019) express that giving high appreciation and recognition will increase work engagement and OCB of the employees. Reward management needs to arrange, because in general, organizations have limited funds compared to large companies. Study in the future needs to analyze the effectiveness of reward forms in creating work engagement and OCB. Management must empower all its employees by providing fair and reasonable rewards and rewards system. In addition, all employees must know and understand the rewards and rewards system clearly and precisely. Thus, they do not feel the gaps of expectation in their work. Therefore, this will increase their work involvement for better performance than before.

\section{Organizational Citizenship Behavior (OCB)}

Podsakoff, MacKenzie, Paine, \& Bachrach (2000) express that employees who help each other do not have to ask for their superiors' assistance, leaving the superiors free for more important tasks. Employees who have good characteristics will tend to have OCB, so that they will work for their organization in a loyal way. Organizational citizenship behavior is a part of every individual. With OCB, it is expected that employees can collaborate with their work environment and can work whole-heartedly, avoid conflicts, and improve efficiency in the organization (Nazma, Emmy Mariantin, 2017). The four factors that affect OCB are individual characteristics (organizational justice, job satisfaction, motivation, organizational commitment, and perception of leader support) (Nazma, Emmy Mariantin, 2017). Kurniawan (2019) states that using the perspective of OCB concept that emphasizes the importance of getting workers to contribute to the company, extra behaviors of the employees together can increase organizational effectiveness, which in this case can also apply to underorganized organizations. With $\mathrm{OCB}$, it is expected that organizations will be able to develop and survive in competition. Besides, we also need to assess the causes of OCB through factors such as perceived organizational support and other psychological factors. Practically, the findings suggest the organization to always implement the company's values to its employees to create agreeableness with the individual values of the employees. Likewise, cognitive (understanding), affective (feeling), and physical (performing) involvements of the employees in crafts and arts need to be maintained because they have been able to maintain organization's reputation by improving the quality of its products (Kurniawan, 2019).

\section{Hypotheses Development \\ Individual characteristics have a positive effect on $O C B$}

Graf (2004) states that skills are very important for every employee to have, to adjust the culture in the organization and create loyalty to the organization. In addition, skills are also needed to get promotion. Personality is described as a self-ideal that affects a person's behavior uniquely. Such behavior can change through various stages in a process, including the process of learning, experience, education, etc. This opinion is also supported by the study of Wahyudi (2014) that personality adjusts to environmental conditions that will affect individual psychology. Thus, environment is very significant to the quality of individual performance. Zehir, Müceldili, \& Zehir (2012) express that OCB yields good and positive results for the organization, increases productivity in organizational performance, facilitates coordination of activities among teams and work groups, and improves the organization's ability to adapt to environmental changes. In addition, OCB is also able to replace insufficient resources for simple maintenance function of the organization. Lee et al. (2013) mention that OCB is defined as an employee's behavior that goes beyond the job. The employee does something more of which is contained in his/her job description, but resulting to benefit the organization. Made (2013) states that individual characteristics indirectly have a positive effect on OCB.

\section{H1: Individual characteristics have a significant, positive effect on OCB.}

\section{Individual Characteristics have a positive effect on Intrinsic}

Motivation, Rusdianti (2017) states that individual characteristics show individual differences in motivation, initiative, resistance in dealing with problems that must be resolved thoroughly. The level of motivation and initiative of an employee is different compared to another. Rusdianti (2017) states that there are several factors that affect on an employee's work motivation, among which are individual characteristics and job characteristics. Rusdianti (2017) states that individual characteristics directly affect on motivation. Thus, if employees have good individual characteristics, they will have direct encouragement, motivation to continue to behave well to others and will create excellent loyalty to the organization.

H2: Individual characteristics have a significant, positive effect on intrinsic motivation.

\section{Intrinsic motivation affects on $O C B$}


Nazma, Emmy Mariantin (2017) mentions that motivation is the desire to do something and determine individual needs. The needs are internal needs, which occur due to lacks in physical and psychological factors that cause individuals to feel the need of encouragement. This encouragement may come from within, which is called intrinsic motivation. If intrinsic motivation appears, then an individual will be responsible for his/her work. OCB is a behavior of an individual choice and initiative. It is not related to the organization's formal reward system but it entirely increases organizational effectiveness. It shows that such behavior is not included in the employee's job description so that if it does not appear, the company will not give punishment

\section{H3: Intrinsic motivation has a significant, positive effect on OCB.}

\section{Individual Characteristics affect on OCB through intrinsic motivation}

Characteristics and motivation directly affect on OCB. Two main components in OCB are compliance, which shows the intention of employees to follow the rules in the organization, and altruism which means employee's voluntary behavior to help others in working (Lee et al., 2013). Such behaviors are carried out, consciously or unconsciously, directed or not directed, to provide benefits and advantages for the company. Thus, individual characteristics can grow or transform into better characteristics and such person can motivate him/herself. By doing so, good characteristics will appear and he/she can carry out his/her responsibility properly, creating loyalty to work better (Nazma, Emmy Mariantin, 2017).

\section{H4: Individual characteristics have a significant and positive effect on OCB through intrinsic} motivation.

\section{Research Method}

The population in this study consists of all employees of BUMDes Panggung Lestari, Panggungharjo Village with a total of 103 employees. The samples in this study consist of 82 employees who worked at BUMDes Panggung Lestari, Panggungharjo Village. This study uses accidental sampling technique, using a questionnaire instrument. The method used is the Slovin method and the data analysis used is the sobel test.

Table 1. Variable \& Indicator

\begin{tabular}{ll}
\hline \multicolumn{1}{c}{ Variable } & \\
\hline Individual & 1. Neurotic \\
Characteristics & 2. Extraversion \\
Bhatti et al (2013) & 3. Openness to Experience \\
& 4. Agreeableness \\
\hline Intrinsic Motivation & 1. The Need for Appreciation \\
Wulandari \& Prayitno & 2. The Need for Task Challenges \\
(2017) & 3. The need to work better \\
& 4. The need to work together \\
& 5. The need to be importantly involved in organizations \\
& 6. The need to have a good relationship with coworkers \\
& 7. The need to participate in a decision-making process \\
& 8. The need to give direction \\
9rganizational & 1. The need to lead \\
Citizenship Behavior & 2. Courtesy \\
Khiabani, Abdizadeh, & 3. Altruism \\
\& Baroto (2016) & 4. Civic Virtue \\
\hline
\end{tabular}

\section{Result and Discusssion \\ Validity Test and Reliability Test}

The validity test result indicates that the value of corrected item-total correlation $>$ r-table $(0.1829)$ or valid. Variable data in this study were tested and have a good reliability value with a significance level of 5\% and Cronbach's alpha based on STD. $>0.06$

\section{Hypotheses Testing}

The results of hypothesis testing in Table 2 shows that $\mathrm{H} 1$ is accepted with a probability value of 0.000 , $\mathrm{H} 2$ is accepted with a probability value of $0.005, \mathrm{H} 3$ is accepted with a probability value of 0.000 . While Hypothesis 4 with a sobel test resulted a value of one-tailed probability of $0.013<0.05$, so that the variable of intrinsic motivation affects as an intervening variable between individual characteristics and OCB. 


\begin{tabular}{ccccccc}
\hline \multicolumn{2}{c}{ Var } & Stand. Coeff. & $t$ & Sig. & $\begin{array}{c}\text { Coeff. of } \\
\text { Determination }\end{array}$ \\
\hline & Independent & Dependent & Beta & & & \\
\cline { 1 - 2 } H1 & IC & OCB & 0.492 & 5.050 & 0.000 & 0.232 \\
H2 & IC & IM & 0.305 & 2.862 & 0.005 & 0.082 \\
H3 & IM & OCB & 0.476 & 4.845 & 0.000 & 0.217 \\
\hline
\end{tabular}

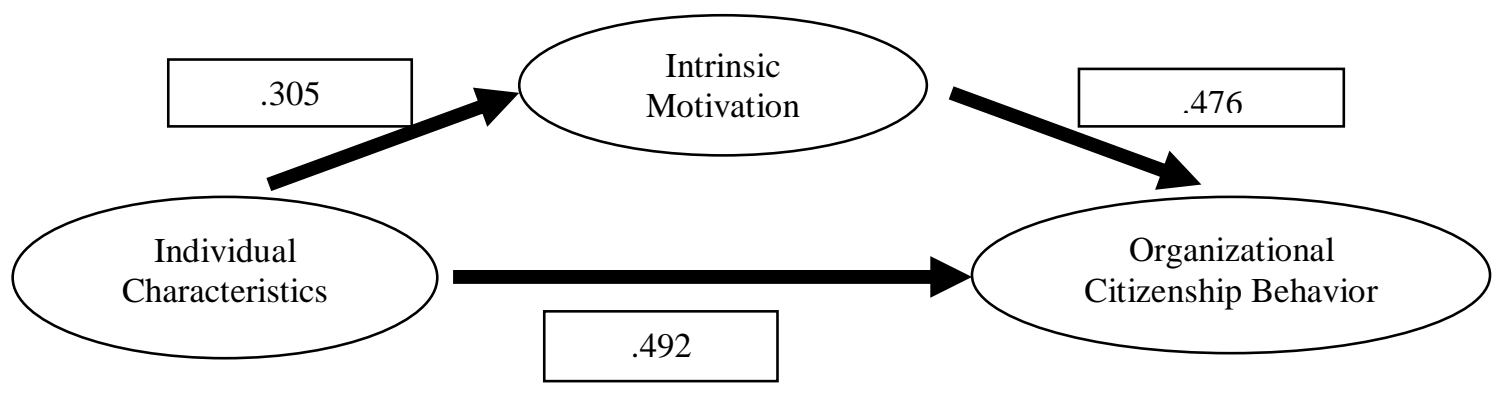

Figure 1. Research Model

Hypothesis testing 4 used Sobel test (Sobel, 1982) with the results as follow.

Table 3. Sobel Test

\begin{tabular}{clll}
\hline Variable & $\begin{array}{c}\text { One-tailed } \\
\text { probability }\end{array}$ & Sig $<\mathbf{0 . 0 5}$ & Remarks \\
\hline IC,IM,OCB & 0.013 & 0.05 & Accepted \\
\hline
\end{tabular}

The first hypothesis testing shows that there is a significant effect of individual characteristics on OCB of the employees of BUMDes Panggung Lestari. Leephaijaroen (2016) individual characteristics and motivation directly affect on OCB. Two main components in OCB are compliance which shows the intention of employees to follow the rules in the organization, and altruism which means employee's voluntary behavior to help others in working. If employees with nature of extraversion (friendly and active) move in a positive direction, it may create sportsmanship (attention) to the organization.

The second hypothesis testing shows that there is a positive, significant effect of individual characteristics on intrinsic motivation of the employees of BUMDes Panggung Lestari. Individual characteristics will support creative behavior that will lead to an increase in organizational creativity, from the ability of individuals to apply experiences in the past. Individual characteristics are assessed by respondents as follows: I am not worried when facing problems (3.89), I am always friendly to anyone (4.30), I am always actively looking for information related to my work (4.21), I do not express my emotions when I'm working (4.00), I want to have many experiences (4.48), I am able to work together to complete work (4.51), I often help my colleagues in terms of completing work (5.00), I am able to work professionally (4.37), all of them have an average value of $>4$ on a scale of 1 to 5 . If experience moves in a positive direction due to friendliness and teamwork through increased intrinsic motivation, such as the need to work together and the need to have a good relationship with coworkers, it is possible to create important needs in the organization. This study is in line with the study of Caligiuri (2000) showing that a person with good individual characteristics has the ability to make a good relationship professionally and easily in achieving a goal.

The third hypothesis testing shows that there is a positive, significant effect of intrinsic motivation on OCB of the employees of BUMDes Panggung Lestari. Intrinsic Motivation is assessed by respondents as follows: I am happy that my work is used as a reference for evaluation by my colleagues (4.06), I am happy to get assignments that I have never done before (4.23), I am motivated when I work better than my colleagues (4.12), I love working in a team (4.33), I am happy to be involved in important matters in the organization (4.23), I am happy to have a good relationship with my coworkers (4.28), I am happy to participate in the decision making process (4.20), I am happy to give direction to my colleagues who gets wrong (3.98), I am motivated to lead in an organization (3.87), all of them have an average value of $>4$ on a scale of 1 to 5. Employees will have intrinsic motivation if they affect Sportsmanship, Courtesy, Altruism, and Civic Virtue and it can be seen from good relationship with coworkers, the ability to give direction, and the ability to work in a team. This study is in line with the study of Larsen, (2016) that having a job that motivates internally can directly create loyalty to employees.

The fourth hypothesis testing shows that there is a positive, significant effect of individual characteristics on OCB with intrinsic motivation as an intervening variable of the employees of BUMDes Panggung Lestari. Employees who have individual characteristics such as neurotic (anxious), extraversion (friendly, active), openness to experience (experience), agreeableness (teamwork) and move in a positive direction through 
intrinsic motivation such as working better, working together, wanting to be involved in organizational matters, are possible to create OCB. Atmaja \& Adnyani (2016) mention that OCB is a behavior that benefits the organization. Thus, Intrinsic Motivation can mediate individual characteristics on OCB as evidenced by data processing using the Sobel Test with a one-tailed probability value of $0.013<0.05$. Hence, it can be concluded that Intrinsic motivation can mediate individual characteristics on OCB.

\section{Conclusion}

The findings show that individual characteristics have a positive, significant effect on OCB, individual characteristics have a significant effect on intrinsic motivation, intrinsic motivation has a positive, significant effect on OCB, and individual characteristics have a positive, significant effect on OCB with intrinsic motivation as an intervening variable.

\section{References}

Abdurahman, L. (2012). Pengaruh Metode Diskusi Kelompok Fungsional Terhadap Pengetahuan Ibu Tentang Tumbuh Kembang Balita (Studi Kasus Di Posyandu Margiraha Yu Iv Desa Pekalongan Kecamatan Bojongsari Kabupaten Purbalingga). Unnes Journal of Public Health, 1(2). https://doi.org/10.15294/ujph.v1i2.3045

Atmaja, I., \& Adnyani, I. (2016). Pengaruh Gaya Kepemimpinan Transformasional Dan Komitmen Organisasional Terhadap Organizational Citizenship Behavior. E-Jurnal Manajemen Universitas Udayana, 5(11), 6088-6115.

Baard, P. P., Deci, E. L., \& Ryan, R. M. (2004). Intrinsic need satisfaction: A motivational basis of performance and well-being in two work settings. Journal of Applied Social Psychology, 34(10), 20452068. https://doi.org/10.1111/j.1559-1816.2004.tb02690.x

Bhatti, M. A., Kaur, S., \& Battour, M. M. (2013). Effects of individual characteristics on expatriates' adjustment and job performance. European Journal of Training and Development, 37(6), 544-563. https://doi.org/10.1108/EJTD-02-2013-0013

Caligiuri, P. M. (2000). The big five personality characteristics as predictors of expatriate's desire to terminate the assignment and surpervisor rated performance. Personnel Psychology.

Drake, A. R., Wong, J., \& Salter, S. B. (2007). Performance: Examining the Impact of. Behavioral Research in Accounting, 19, 71-89. https://doi.org/10.2308/bria.2007.19.1.71

Graf, A. (2004). Expatriate selection: An empirical study identifying significant skill profiles. Thunderbird International Business Review, 46(6), 667-685. https://doi.org/10.1002/tie.20030

Hidayatullah, R. M., Noviekayati, I., \& Saragih, S. (2018). Efektivitas Spiritual Emotional Freedom Technique (Seft) untuk Menurunkan Kecemasan Santri Baru Ditinjau Dari Tipe Kepribadian. (45), 144156.

Johari, J., \& Yahya, K. K. (2009). Linking Organizational Structure, Job Characteristics, and Job Performance Constructs: a Proposed Framework. International Journal of Business and Management, 4(3). https://doi.org/10.5539/ijbm.v4n3p145

Khiabani, M., Abdizadeh, M., \& Baroto, M. (2016). Identifying the Impact of Spiritual Leadership on Organizational Citizenship Behavior in the Iranian Healthcare Industry. British Journal of Economics, Management \& Trade, 11(1), 1-15. https://doi.org/10.9734/bjemt/2016/21678

Kurniawan, I. S. (2019). Pengaruh Value Congruence dan Core Self-Evaluations Terhadap Job Engagement Dan Dampaknya Pada Organizational Citizenship Behavior. Jurnal Kewirausahaan Dan Bisnis, 23(12). https://doi.org/10.20961/jkb.v23i12.27492

Kurniawan, I. S., \& Hutami, L. T. H. (2019). The Mediation of Job Engagement to Rewards and Recognition toward Organizational Citizenship Behavior and Task Performance. 86(Icobame 2018), 48-52. https://doi.org/10.2991/icobame-18.2019.10

Larsen, V. (2016). Consumer Satisfaction and the Marketing of Voluntarism: The Case of Appalachian Mountain Housing. Journal of Consumer Satisfaction, Dissatisfaction, and Complaining Behavior, 8(November).

Lee, U. H., Kim, H. K., \& Kim, Y. H. (2013). Determinants of Organizational Citizenship Behavior and Its Outcomes. Global Business and Management Research: An International Journal, 5(1), 54.

Leephaijaroen, S. (2016). Effects of the big-five personality traits and organizational commitments on organizational citizenship behavior of support staff at Ubon Ratchathani Rajabhat University, Thailand. Kasetsart Journal of Social Sciences, 37(2), 104-111. https://doi.org/10.1016/j.kjss.2015.03.002

Made, D. (2013). The International Journal of Management the Influence of Personality and Organizational Culture on Employee Performance Through Organizational Citizenship Behavior. The International Journal of Management, 2(4), 35-42.

Nazma, Emmy Mariantin, S. S. (2017). Pengaruh Iklim Organisasi, Motivasi Dan Keadilan Organisasi Terhadap Organizational Citizenship Behavior (OCB). E-Jurnal Manajemen Unud, 6(9), 4659-4688.

Podsakoff, P. M., MacKenzie, S. B., Paine, J. B., \& Bachrach, D. G. (2000). Organizational citizenship behaviors: A critical review of the theoretical and empirical literature and suggestions for future research. Journal of Management, 26(3), 513-563. https://doi.org/10.1177/014920630002600307 
Puspitasari, S. (2019). Pengaruh Kepemimpinan Spiritual Terhadap kepuasan kerja karyawan melalui motivasi intrinsik dan komitmen organisasi. Ekobis, 20(1), 73-84.

Rusdianti, D. K. dan E. (2017). Analisis Pengaruh Karakteristik Individu, Komitmen Organisasi, Dan Kepuasan Kerja Terhadap Kinerja Karyawan Dengan Motivasi Sebagai Variabel Intervening. 60-76.

Sobel, M. E. (1982). Asymptotic Confidence Intervals for Indirect Effects in Structural Equation Models. Sociological Methodology, 13(1982), 290. https://doi.org/10.2307/270723

Wahyudi, D. (2014). faktor-faktor yang mempengaruhi konsumen dalam memilih sepeda motor harley davidson. Jurnal Ilman, 1(1), 83-92.

Wulandari, D. A., \& Prayitno, A. (2017). Pengaruh Motivasi Kerja Dan Lingkungan Kerja Terhadap Organizational Citizenship Behavior Dengan Komitmen Organisasi Sebagai Variabel Intervening. Jurnal Penelitan Ekonomi Dan Bisnis, 2(1), 46-57. https://doi.org/10.33633/jpeb.v2i1.2234

Zehir, C., Müceldili, B., \& Zehir, S. (2012). The Impact of Corporate Entrepreneurship on Organizational Citizenship Behavior and Organizational Commitment: Evidence from Turkey SMEs. Procedia - Social and Behavioral Sciences, 58, 924-933. https://doi.org/10.1016/j.sbspro.2012.09.1071 